を用いてピント合わせを行うことが必要になる。このよ うな装置を持つことはこの測定機としては 必要条件とな る場合が多いので実際上は $\theta_{3}$ による制限は考えなくて もよかろう。ただ顕微鏡のピント合わせの微動装置の送 りの真直度は測定精度に等しいかこれより小さい值にと つておかなければならない。

\section{9. オートコリメータとの比較}

普通の 1 'よみのオートコリメータの対物レンズの焦 点距離は約 $300 \mathrm{~mm}$, 接眼レンズの倍率は×10, 程度 の ものが多い。このようなオートコリメータで值径 $1 \mathrm{~mm}$ の小面積の平面を 観測する場合コリメータレンズの有効 直径は $1 \mathrm{~mm}$ となる。この場合点光源から出た光の回折 縞の第 1 次の暗環の半径は 明視の距離に颃いて $1.22 \times 6$ $\times 10^{-4} \times 300 \times 10=2.2 \mathrm{~mm}$ となる。またこの場合 1 'の目 盛は明視の距離に沶いて $2 \times 2.9 \times 10^{-4} \times 300 \times 10=1.7$ $\mathrm{mm}$ である。この状態では 1 'の精度で角度の定測を行 うに恰閴がある。
一方顕微鏡系を用いた方法では $m=10, n=3$ とすれ ば, $\Delta\left(\theta=1^{\prime}\right)=0.011 \mathrm{~mm}$, 分解能を $E$ として $10 m E=$ $0.12 \mathrm{~mm}$ となる。この值は明視の距離に拉けるものであ り, 肉眼の最小分解角 $\omega=2^{\prime}$ より小さくなる。すなわち 像のボケは肉眼ではみとめられない。

以上の計算から微小平面の角度測定に和いては普通の オートュリメータでは本文にのべた方法より精度がおち ることになる。

\section{0. 桔 言}

顕微鏡光学系を用いて 微小平面の法線方向の検出を行 い， あるいは微小な角度の偏差測定を行う方法を考案し これによる測定の種々の制限条件について考えた。この 結果微小平面を $1^{\prime}$ 程度の精度で 角度測定を行う場合に は相当好結果が得られることが明らかとなつた。この方 法はビッカースダイアモンド圧子の形状測定に 用いるつ もりで行つたものである。実際の応用については次報に ゆづることとする。（1959，3月24日 受付）

\title{
ミニアチュア球軸受について
}

一鋼球ラッピングに怙ける切削抵抗 $(2)^{*}$

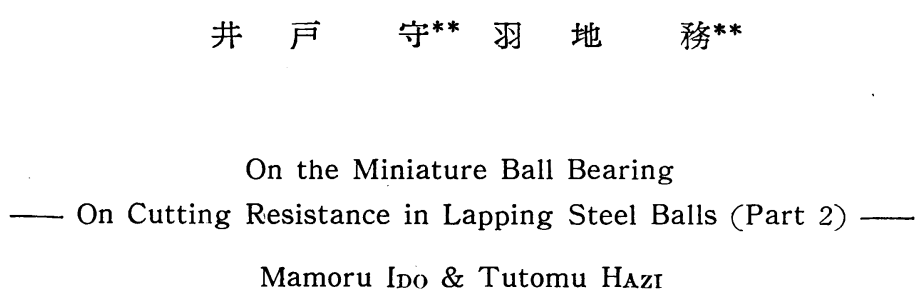

In this paper continued from part 1, we made an experiment on the effect of lapping pressure, lapped quantity, sphericity of balls used and supplying interval of lapping compound upon cutting resistance when the radius of steel balls was about $1 \mathrm{~mm}$.

Then we found following results,

(1) in the case of cast iron lap, there were limits in suitable lapping pressure according to the ball size, and the supplying interval of lapping compound had no influence on them,

(2) in the case of suitable lapping condition, the cutting resistance was proportional to lapping pressure or the lapped quantity, and its proportional constant was different according to lap materials,

(3) in the case of nylon lap, lapped quantity was not much connected with lapping pressure, but sphericity was proportional to lapping pressure,

(4) in the case of cast iron and nylon lap, variation of the cutting resistance was comparatively small, and the sphericity increased when cutting resistance decreased gradually. 


\section{1. 緒 言}

前報1) では切削抵抗がラッピング条件によつて変化す る状態を調べ，これと関連するラップ量，真球度捺よび 砥粒あるいは切屑の状態などから切削抵抗の性状飞つい て研究した。そしてラップ量扔よび真球度はラップ剂の 状態と切削抵抗との観察結果から，切削抵抗の変化状態 そよつてその良否が判定できることが判明した。

ここではこれらの結果をもとに，ラップ圧あるいはラ ップ剂の補給，またはラップなどによつてラップ量，真 球度の変化する状態を切削抵抗の測定，砥粒あるいは切 甬の顕微鏡観察などの実験結果から考察し，このときの 最適のラッピング条件について研究した結果を報告す る。

\section{2. 実験の方法}

使用したラッピング装置括よび 測定装置は前報と同じ であるが，ラッピング条件がつぎの点で異なつている。

ラップはショア硬度 32の普通鋳鉄のほかとポリアミド 樹脂（ナイロン 66）を使用し, 鋳鉄ラップとの接触の状 態, 機械的性質などの相違から生ずる変化を比較検討し た。な招ナイロンラップは前報2)のごとく，鋼球ラッピ ングでは相当有効なラップであることが判明している。

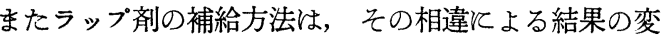
化を明らかてみるために, WA 600 \# と石油との容積混 合比が 1:4のラッブ剂を, 5 分と20分間隔の 2 種類につ いて実験した。ただし20分間隔補給の場合は15～16秒に 1 滴（約 $40 \mathrm{mg}$ ) ずつの石油を滴下した。そしてラップ の回転数はいずれも58rpm であり，ラッピング時間は 1 時間である。

供試資料は前報同様に $700^{\circ} \mathrm{C} て ゙$ 焼鈍した高炭素クロー ム鋼を仕上げたもので，表 1 のごとく19種の資料につい てラップ圧およびラップ剂つ補給方法を変化させて 実験 した。表中のN符号はナイロンラップを使用した場合で あり，このときのラップ量を考察するために別にラップ 液のみによる60g/個のラッピングも行なつた。な和各種 別の鋼球数は各々 103 個からなつている。

\section{3. 実験結果と考察}

3.1 ラップ压とラップ量抒よび真球度との関係

因1はラップ圧に対するラップ量変化の実験結果であ

* 昭和33年 5 月 16 日 精機学会春季講演会で一部発 表, 昭和33年10月9日精機学会秋季講演会で発 表

**大阪府立大学工業短期大学部 正会員
表 1 対ラップ圧用資料

\begin{tabular}{|c|c|c|c|c|}
\hline 資 料 & 荷 $(\mathrm{g})^{\text {重 }}$ & $\left|\begin{array}{c}\text { ラップ剂 } \\
\text { 補給間隔 } \\
\text { (分) }\end{array}\right|$ & $\begin{array}{c}\text { 平均值径 } \\
\text { (mm) }\end{array}$ & $\begin{array}{c}\text { 標準偏差 } \\
(\boldsymbol{\mu})\end{array}$ \\
\hline 1 & \multirow{2}{*}{100} & 5 & 2.0780 & 4.08 \\
\hline 2 & & 20 & 2.0775 & 3.95 \\
\hline 3 & \multirow{2}{*}{80} & 5 & 2.0816 & 5.17 \\
\hline 4 & & 20 & 2.0771 & 4.72 \\
\hline 5 & \multirow{2}{*}{60} & 5 & 2.0777 & 4.45 \\
\hline 6 & & 20 & 2.0775 & 3.95 \\
\hline 7 & \multirow{2}{*}{40} & 5 & 2.0820 & 5.09 \\
\hline 8 & & 20 & 2.0834 & 5.10 \\
\hline 9 & \multirow{2}{*}{20} & 5 & 2.0774 & 4.26 \\
\hline 10 & & 20 & 2.0775 & 3.70 \\
\hline $1 \mathrm{~N}$ & \multirow{2}{*}{30} & 5 & 2.0732 & 3.25 \\
\hline $2 \mathrm{~N}$ & & 20 & 2.0752 & 3.75 \\
\hline $3 \mathrm{~N}$ & \multirow{2}{*}{60} & 5 & 2.0793 & 4.06 \\
\hline $4 \mathrm{~N}$ & & 20 & 2.0725 & 3.75 \\
\hline $5 \mathrm{~N}$ & \multirow{2}{*}{90} & 5 & 2.0780 & 4.12 \\
\hline $6 \mathrm{~N}$ & & 20 & 2.0760 & 3.55 \\
\hline $7 \mathrm{~N}$ & 30 & 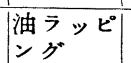 & 2.0740 & 3.17 \\
\hline $8 \mathrm{~N}$ & 60 & נر & 2.0728 & 3.01 \\
\hline $9 \mathrm{~N}$ & 90 & " & 2.0719 & 3.23 \\
\hline
\end{tabular}

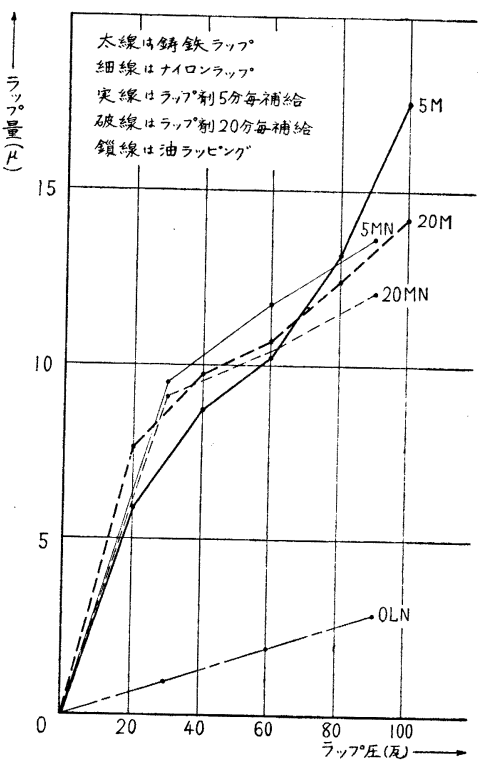

図 フ ラップ圧によるラップ量の変化

り，ラップ量は直径の減少量として表わしたものであ 


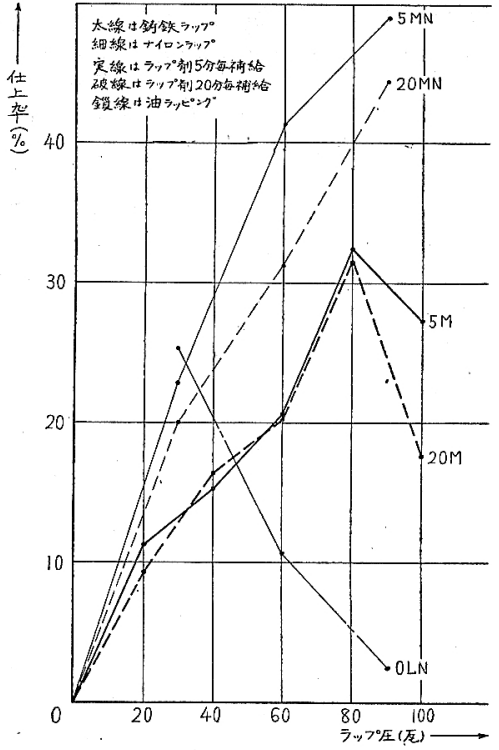

図 2 ラップ压による仕上率の変化

る。また図 2 ねこのときの真球度の変化状態で，各鋼球

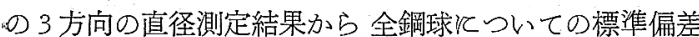
を求め，標準偏差の減少割合としての仕上率を綐軸にと

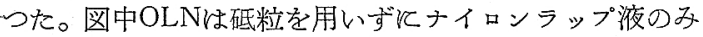
を前記同樣に滴下したときの結果である。

一般的傾向と乙ては前報 ${ }^{3}$ と同様であり，鉱鉄ラップ のときのラップ量は， ラップと鋼球の直接接触の割合， 砥粒の切削能の変化とラップの加工硬化，ラップ抄の量 または浱度などに関連して 40〜70 g/個の範囲では一様な 比例状態から滢かながら減少している。そして低圧部て は20分間隔補給，高圧部では 5 分間隔補給の場合はラッ プ量がより大きいのは， ラップ剤の切削有効時間の差が 表われているものと思われる。しかしながらラッブ剂の 補給が5 分間隔というのは，ラップ板の回転汇伴つてそ の周辺から排出されるラップ剂の状態からも，また常識 的飞も明らか補給過多であり，20分間隔は前報4)の図 5あるい性図6から判定すれば，ラップ量汇対しては比 較的有效江砥粒の働く時間である。図了惊上投影機 (120倍)《よる各補給間隔の場合のラップ剂の状態であ り，切痛社適当汇排除されて和り，平均した切削抵抗の 差後述のごとく少いが，䃌粒の状態は相当異なつてい る。従つてラップ圧が 60 ８0 g/個の範囲では，その補給 方法汅は関係なくラップ量がほぼ一定になることが推定 され，鋼球の直径が異なればこの圧力範囲も変移するも のと思われる。このことからこの圧力範囲以下の圧力で

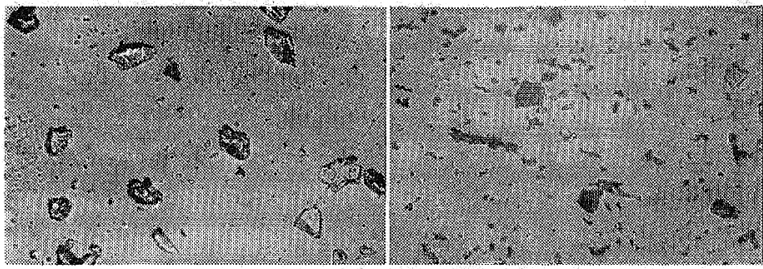

(a) $40 \mathrm{~g} 58 \mathrm{rpm} 5$ 分每 1 時間 (c) $40 \mathrm{~g} 58 \mathrm{rpm} 20$ 分每 1 時間

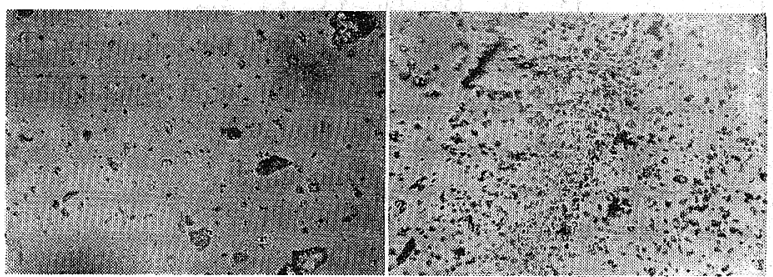

(b) $100 \mathrm{~g} 58 \mathrm{rpm} 5$ 分每 1 時間 (d) $100 \mathrm{~g} 58 \mathrm{rpm} 20$ 分間 1 時間

図 3 鋳鉄ラップにおいて衼給間隔を变えた場合 $(\times 120 \times 1 / 2)$

はさらに補給間隔を長くすればより有效なラッピングが 行なわれ，この圧力以上の圧力ではとの補給間隔をさら

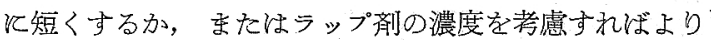
有効なラッピンダとなる可能性が考えられる。従つてこ の最適の圧力簯囲林 鋼球直径とラップ剂の濃度によつて 異なることが予想され，この圧力では秪粒は有効飞㗢 き，図 2 からも判るごとく真球度汇を好結果をるたらす こと汇なる。

ナイロンラップでは砥粒の破砤が少く，ナイロン詨鋼 の磨耗特性 ${ }^{5}$ から低圧部ではむしる銀鉄ラップよりも若 干多いが，高圧になるに従つて增加割合が少くなる。そ して油ラッピングのラップ量からみれば， ラップ量の增

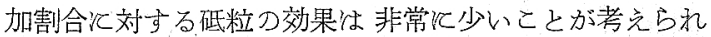
る。しかしながら真球度化対してはラップ剂の同一補給 間隔でも圧力の増加比例して上昇しているから，砥粒 などの埋込みとよる見掛上の表面硬化は 圧力の増加汇対 して徐々飞堌加し，接触面積も当然大きくなる加ら，ラ ップ剤つ補給間隔あるいはラップ圧炕上る相違が表われ ているものと思市机る。この上うと見掛上の表面硬化低

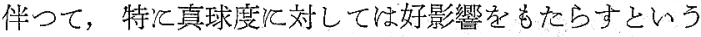
こと社，油ラッピングの場合のラップ量と真球度とがラ ップ圧飞対して相反するという結果の事実からも推定さ

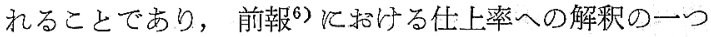
の裹付けといえる。

3.2 ラップ圧と切削抵抗との関係

ラップ剂の各補給閏隔化 対する各ラップ圧の場合の切 削抵抗の変化は図 4 杼よび図 5 である。図の左下の各值 は砥粒を加党ないときの抵抗であり，鋳鉄ラップでは抵 


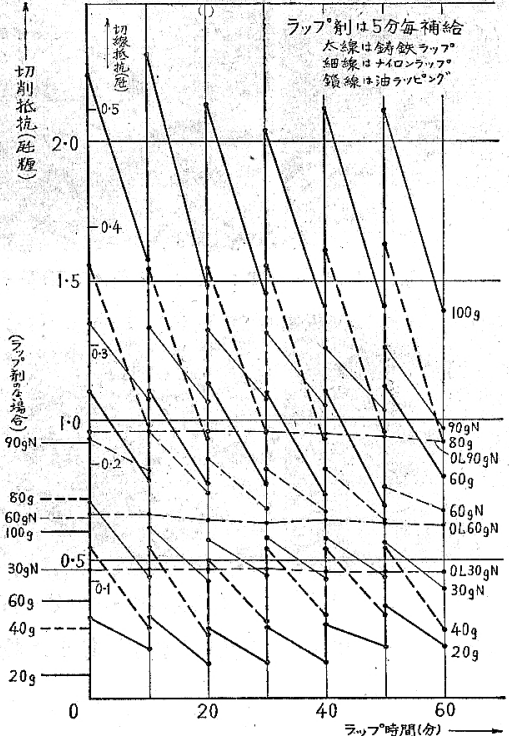

図 4 切埥抵抗の時間的变化 (1)

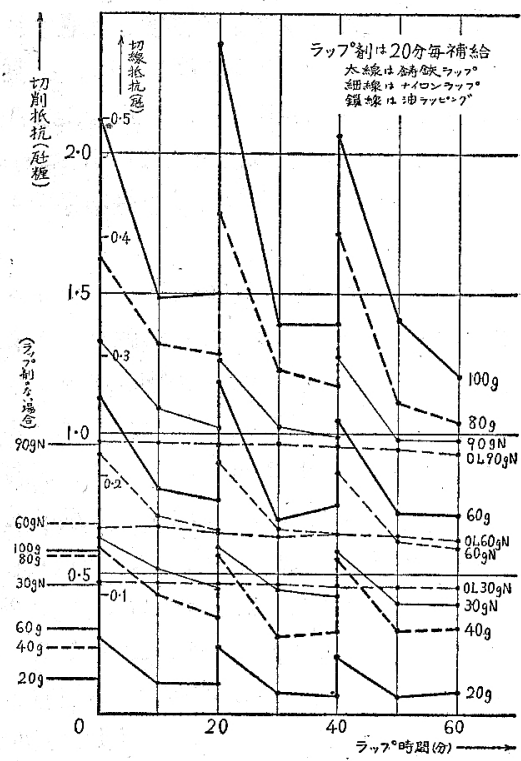

图 5 切邻抵抗の時間的变化 (2)

抗がラップ压比例しない原因は，主として真球度の相 䔔に上る衝撃抵抗の差为出ていることは表 1 からを明ら かである。またナイロンラップで性真球度の如何にかか

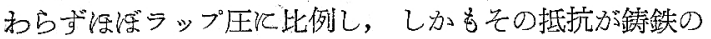

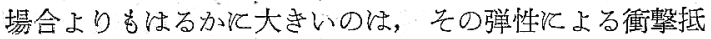
抗が少く，接触面積と摩擦特性が原因である。

ラップ压汶対する切削抵抗は，鋳鉄ラップとナイロン
で注定量的炕も定性的汇も多少異なつている。すなわち

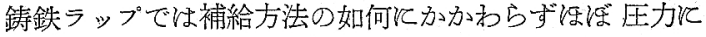
比例した切削抵抗を示し，補給前後の差が特に20分間隔 では大きい。そしてこのときの衙撃抵抗の差が碟粒のな い場合はどとは現われず，5分間隔ではよりこの傾向が 顕著である。これ恃真球度の早急な変化を意味していな いことは, 前報》の図 7 , 図 8 亿示した時間的な仕上率 の変化と切削抵抗との比較からも明らかであり, 碰粒が

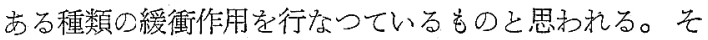

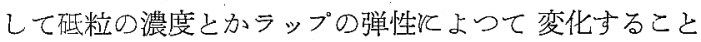
は, ナイロンラップのときの切削抵抗の変化からを明ら かである。

すなわちナイロンではラップ玨が90 g でもラップ斉の 補給前後の差が，鉦鉄ラップの $40 \mathrm{~g}$ ぐらい反相当し，䃌 粒のない場合の抵抗飞比して切削抵抗が極端飞大きくは ならない。これ《注図 6 亿示す碰粒の状態も多少の影響 のあることが考克られるが，図3と比較したときの切削 抵抗の結果からは少いものと思われる。

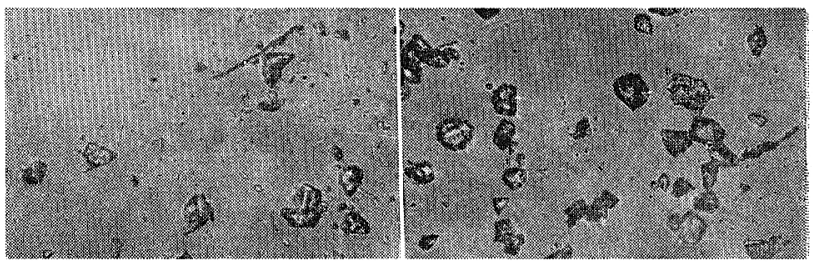

(a) $30 \mathrm{~g}$ ナイロン $58 \mathrm{rpm}$ 5 分毎 1 時間 (c) $30 \mathrm{~g}$ ナイロン $58 \mathrm{rpm}$ 20 分毎 1 時間

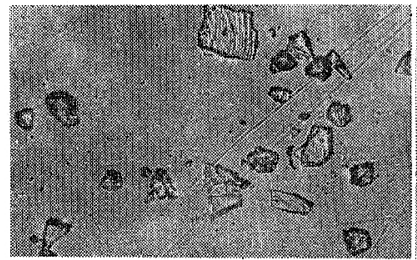

(b) $90 \mathrm{~g}$ ナイロン $58 \mathrm{rpm}$ 5 分每 1 時間

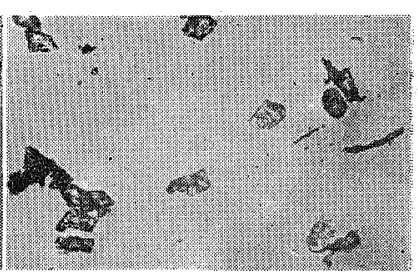

(d) $90 \mathrm{~g}$ ナイ ロン $58 \mathrm{rpm}$ 20分毎 1 時間
図 6 ナイロンラップにおいて補給間隔を変えた場合 $(\times 120 \times 1 / 2)$

図 7 はラップ圧と切削抵抗との関係である。図4执よ び図 5 から求めた切削抵抗は，抵抗の時間的な変化の状 態と前記の原因加 $5 ， 5$ 分間隔補給の場合《は補給前の 抵抗の平均値，20分間隔で補給前と中間の10分に沶け る抵抗との平均值を採用した。

この結果によれば補給方法による相異は少く，ラップ 材質によるその傾向の変化が明䐲涀われている。とし ていずれる泳ほ直線近い比例関係をしていることが判 


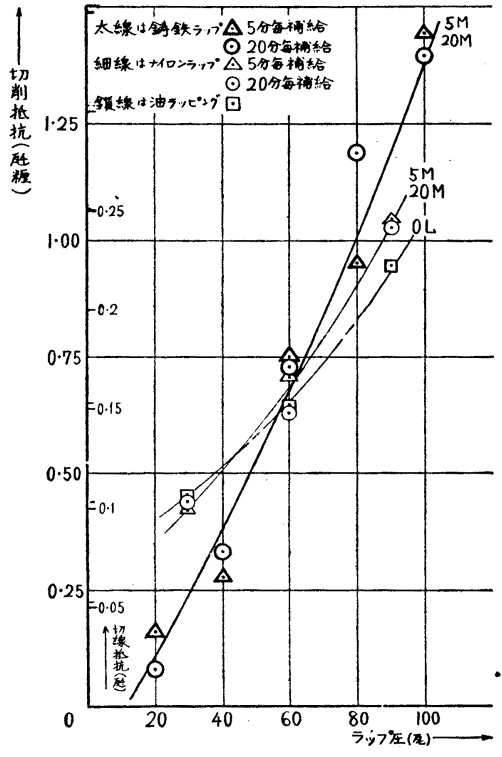

図7ラップ压による切制抵抗の変化

る。

一般のころがり摩擦とはその機構をたは条件も根本的 飞異なり, 研粒の存在のほか飞機構的にも spinning が 生ずるか，巨視的な転り摩擦として切削抵抗をみれば，

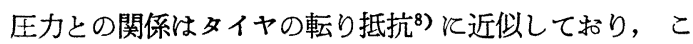
の場合のラッブはその機械的性質が相当異なるけれど も，抵抗の速度項が硬度によつて変つてくる というこ とを考慮すれば，普通の転り摩擦と同傾向を示している と言える。しかしこの定量的な結論はな招多くの資料に また极な゙なない。

\section{3 切削抵抗とラッブ量との関係}

図 8 亿示すように，切削抵抗はラッピング条件が同一 のときはほぼラップ量に直線的な比例をする。そしてこ の関係は補給方法またはラップの種類によつて 比例常数 が異なる。

ナイロンラップでは油ラッピングと20分間隔補給とで は，その増加割合がほとんど同じであり，本実験の圧力 範囲内では圧力の増加に対して 砥粒の影響はほとんど変 らない。従つてラップ量に対する効率からは, ラップ剂 の濃度をもつと増加せしめるとか，ナイロン成形の際に 䃌粒を混入するというのも一つの方法である。

\section{4. 結 諭}

ラッブ剂の補給方法掞よびラップの種類を変化させ て，䃌粒あるいは切屡の状態をる考虑して切削抵抗とラ ップ圧との関係を求め，切屑の排出が適当に行なわれる

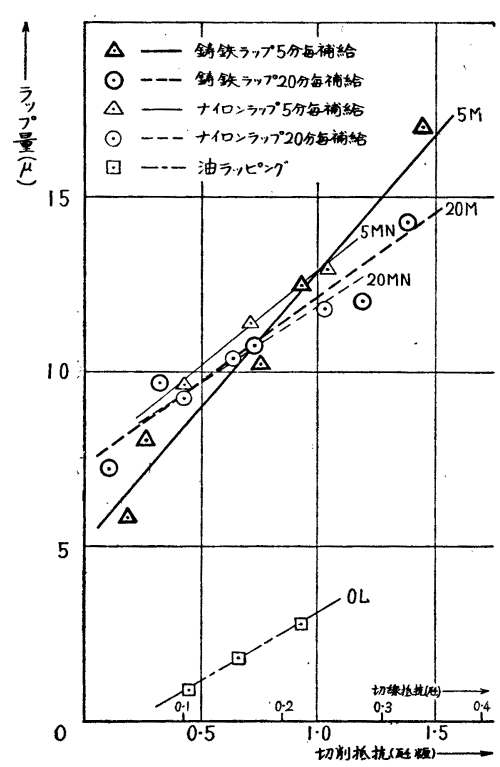

図 8 切制抵抗によるラップ量の変化

ようなラッピングに 括ける最適ラッピング条件などにつ いて考察した。

(1) 鋳鉄ラップスよる鋼球ラッピングでは，その鋼球 の直径に適応したラップ圧のある範囲があり，この圧力

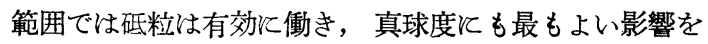
与える。そして本実験に拈けるラッピング条件のこの圧 力では補給方法には関係なく，鋼球径が異なれば圧力範 囲も変移し，この圧力以外ではラップ剂または補給間隔 を考慮すればより有効なラッピングが行なわれる。

(2) 適当な同一ラッピング条件では，ラップ圧と切削 抵抗またはラップ量と切削抵抗はほほ值線的な比例関係

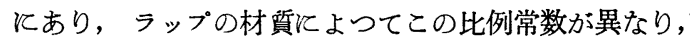
ラップ圧に対する切削抵抗は通常の圧力と摩摖抵抗との 関係近いものとなる。

(3) ナイロンラップマ拈けるラップ量と 寄与する砥粒 の影響は，ラップ圧の変化対してはほとんど認められ ないが，真球度はラップ圧に比例して上昇する。

(4) ラップが鋳鉄とナイロンだけの切削抵抗の結果か らは, 抵抗の振動と変化そのものが比較的少く, 乙かも 抵抗が漸减する場合が結果的飞よく，ラップ材質が軟い ものでは砥粒の支持力と破砕との関係から，上り高圧の 場合が好影響をもたらす。(1958，12月26日受付）

\section{参考文献}

1) 井戸, 羽地：ミニアチュア球軸受について（銅球 ラッピングにおける切制抵抗 I), 精密機械, 
Vol.25, No. 7 .

2) 井戸, 羽地：ミニアチニア球軸受について, 精密 機械, Vol. 24, No. 5, (1958) p. 254.

3) 井戸, 羽地 : 前出 (2)

4) 井戸，羽地：前出 (1)

5) Wall : Nylon in Bearing \& Gear, Prod. Engg., Vol.21, No.7, (1950) p. 102.
松原: 最近の摩耗理論とその応用, 機械の研究, Vol. 4, No. 2, (1953) p. 127.

6) 井戸, 羽地 : 前出 (2)

7) 井戸, 羽地 : 前出 (1)

8) 前田外：自動車, 機械学会, (昭28) 55 .

9) 久田：転り摩擦の研究, 機械試験所報告, 3 (19 50) 13.

\title{
干涉縞計数方式による長さの測定について (IV)
}

\section{一一試作された干涉縞計数装置について—}

\author{
桜 井 好 正* \\ Length Measurement by Fringe "Counting (IV) \\ Y. SAKURAT.
}

In order to measure the length by counting the number of interference fringes observed in a field of interferometer, the counting apparatus was made on trial. This apparatus is composed of the phototubes to pick up the interference fringes, reversible electronic and mechanical counter, and cathode ray tube to read the fringe fractions. Counting rates in excess of $10 \mathrm{KC}$ have been achieved with this apparatus.

\section{1. 干涉縞計数装置の構成}

光波干渉計で一つの反射鏡を固定し，他方の反射鏡を 測定すべき長さだけ移動したとき，視野にあらわれる干 涉縞は反射鏡が波長の半分だけ移動する毎に，1つずつ 移動することはすでて知られている。したがつて干涉縞 の移動数をその端数も含めて数光れば 長さが測定できる わけである。このような方法で長さを測定するとは，2 光線の等厚干渉を利用したマイケルソン型干渉計が最も 適当である。特汇その反射鏡江直角プリズムあるいは 3 面直角プリズムを使つたものは，干涉縞を光電管で取出 す場合飞, 光電管に十分な光量を与えることができ， た精度の点でも最も優れたものである。干涉縞の計数装 置を製作する場合とは，次の諸点を考慮する必要があ る。

i）干渉編が正確に数えられ，かつその端数まで測定 されること。

ii) 計数が可逆的であること。

iii）計数速度が 0 サイクルから10キロサイクル以上に

* 中央計量検定所 正会員
及ぶこと。

iv）干渉縞の鮮明度の変化対して応じうること。 等である。光波干涉法で長さを測定する場合飞使用する 波長は，普通 $0.4 \mu$ 以上である。干涉縞は反射鏡が $1 / 2$ 波 長移動する毎に，1つずつ送られるから，0.1 それ以上の精度で測定する場合には，干渉縞の計数に間 違いが絶対にないことは勿論，その端数も必要な精度で

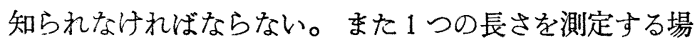
合, その両端での位置ぎめ操作は，一般に一度で完了す ることは少なく，再三合せ直した後正しい位置に合せら れることが多い。をた振動等で反射鏡が 1 つの位置を往 復する場合も怙こりうる。このような場合にも正確な計 数を行うには，正負弁別できる計数装置が必要である。 また位置ぎめされた場合には，反射鏡はその位置で停止 するから，計数速度の下限は0サイクルでなければなら ない。またその上限は速い程測定時間を短縮するが，10 キロサイクル程度あれば十分である。最後にスペクトル 線は一般に波長幅を持つているから，干渉縞の鮮明度は 光路差の増大と共泜下する。したがつて反射鏡を移動 するときの光電管からの交流出力の振幅は 次第少ささ なるわ汁である。このようと出力振幅が変化しても計数 